\title{
Pemoline and Tetramisole 'Positives' in English racehorses following Levamisole administration.
}

Gutierrez, J., ${ }^{1}$ Eisenberg, R. L., ${ }^{2}$ Koval, N. J., Armstrong, E. R., ${ }^{1}$ Tharappel, J., ${ }^{1}$

Hughes, C. G., ${ }^{1}$ Tobin, T. ${ }^{1}$

\author{
${ }^{1}$ Department of Veterinary Science \\ The Maxwell H. Gluck Equine Research Center \\ University of Kentucky \\ Lexington, KY 40546 USA
}

${ }^{2}$ Frontier Biopharm
P. O. Box 614

Richmond, KY 40476 USA

rod@frontierbiopharm.com

\section{ABSTRACT}

Pemoline is a central nervous system stimulant that has been used to treat attention-deficit hyperactivity disorder and narcolepsy in humans; its identification in horses could be considered evidence of attempts to influence performance. Two recent pemoline 'positives' in English racehorses led us to review the chemical relationships between tetramisole, levamisole, aminorex and pemoline. Pemoline is a simple oxidation product of aminorex, which has been shown in the United States and elsewhere to be an equine metabolite of levamisole. Based on the clear structural relationships between aminorex and pemoline, we conclude that levamisole can metabolise to pemoline in horses and that pemoline identifications in horses post levamisole administration are likely to be associated with levamisole administration. Levamisole should not be administered to horses about to compete because of its ability to metabolise to two central nervous system stimulants, aminorex and pemoline.

KEY WORDS: Horses, tetramisole, levamisole, aminorex, pemoline, metabolism, drug 'positives'.

Irish Veterinary Journal

Volume 63 Number 82010

Pemoline, [(RS)-2-amino-5-phenyl-1,3-oxazol-4(5H)-one] is a central nervous system stimulant used to treat attention-deficit hyperactivity disorder (ADHD) and narcolepsy in humans (Molina and others 1981). In horse racing, pemoline is classified as an Association of Racing Commissioners International (ARCI) 'Class 1' foreign substance, i.e., an agent with high potential to influence performance (Tobin 1981 and ARCl website). Pemoline is unusually identified in a post-race sample, and its identification would usually be interpreted as an attempt to improperly influence performance. However, an entirely innocent explanation is possible for such pemoline identifications, as we will now set forth.

The explanation is based on the fact that in the horse, and possibly other species, pemoline is a metabolite of levamisole, an anthelmintic and immune stimulant not uncommonly administered to horses (Mohri and others 2005). The recommended dose in the horse is $2 / \mathrm{mg} /$ $\mathrm{kg}$ orally, once a day for three-to-five days, as an immune modulator (Britt and Byars, 1997). Furthermore, in the horse levamisole, metabolism has recently been shown to produce a closely related substance, aminorex (Barker 2008, Ho and others 2009, Pellegrini, 2010). Aminorex, which is structurally related to levamisole and pemoline (Figure 1), is a central nervous system stimulant which was marketed as a prescription anorectic in Europe, but withdrawn when it became associated with pulmonary hypertension (Gurtner 1985). In the United States, Aminorex is a DEA Schedule 1 substance and an ARCI 'Class 1' substance, like pemoline. In the United States, the link between levamisole administration and aminorex identifications has been associated with a series of no fewer than 82 aminorex 'positives' in post-race urines. These aminorex 'positives' started with a single identification in Belgium, then, in the United States, first in October 2004 in Ohio, and later in both Pennsylvania and Ontario (Weber 2010) as set forth in Table 1. In Pennsylvania, beginning 
in October of 2005, testing indicated detections of aminorex in both blood and urine samples and by November 2006 aminorex 'positives' had been reported in all four Pennsylvania racetracks (Mushalko, 2010, Uboh, 2010). Each of these jurisdictions is a major North American racing jurisdiction, testing in the order of 15,000 samples per year or more at multiple racing venues, both Thoroughbred and Harness, in each jurisdiction.

Table 1: Time Sequence of Aminorex "positives" in North America, 2004-2009

\begin{tabular}{|l|l|l|l|l|l|l|l|}
\hline State/Province & 2004 & 2005 & 2006 & 2007 & 2008 & 2009 & Total \\
\hline Ohio & 8 & 2 & 9 & 4 & 1 & 4 & 28 \\
\hline Pennsylvania & & 4 & 32 & & & & 36 \\
\hline Ontario & & & & 18 & & & 18 \\
\hline Totals & 8 & 6 & 41 & 22 & 1 & 4 & 82 \\
\hline
\end{tabular}

As shown in Table 1, 'positive' reports for aminorex in the US and Canada peaked in 2006 with 41 total, followed by 18 in 2007, principally in Ontario. It seemed unusual that these aminorex 'positives' continued to occur in the face of significant penalties against the horsemen involved: the penalty in Ohio usually being a fine of about $\$ 500$, loss of purse and a six-month suspension.

The first direct association between these aminorex 'positives' and levamisole administration was made by $\mathrm{Dr}$ Frank Pellegrini of Freedom Health, LLC, whose companies' products had been linked to the aminorex identifications. Dr Pellegrini made the aminorex/levamisole association in about September 2006 when at least one of a group of horses that he had treated therapeutically with levamisole gave rise to an Ohio aminorex 'positive' (Tobin 2010). This finding led Dr Pellegrini and Freedom Health LLC to perform a carefully designed series of experimental administrations, using a number of different commercial levamisole sources, a number of selected Freedom Health products and two other non-levamisole wormers, Panacur and Safe-Guard. The post administration urine samples were then analyzed under contract by Industrial Laboratories in Denver, CO, and this work confirmed Dr Pellegrini's proposed levamisole/aminorex relationship (Pellegrini 2010). The formal reporting of these findings on or about March $17^{\text {th }} 2008$ by Freedom Health, LLC, led to an abrupt decline in the number of aminorex 'positive' calls (Table 1). This levamisole to aminorex transformation was soon confirmed by the work of Dr Steve Barker of Louisiana State University (Barker 2008) and later by Ho and others (2009).

About this time our group in Kentucky was researching the aminorex situation on behalf of Pennsylvania horsemen, and a proposed chemical levamisole/aminorex transformation mechanism was communicated by $\mathrm{Dr}$ Rodney Eisenberg of Frontier Biopharm to Dr Mike Weber in Ontario (Figure 1). In summary, work in 2006-2007 clearly established that aminorex is found in equine urine post levamisole administration and established a proposed chemical mechanism for these transformations. These findings led to forensic and regulatory re-evaluation of the significance of the aminorex 'positives' reported in a number of jurisdictions.

Review of the data presented in Table 1 shows differing time courses of aminorex "positives" in each jurisdiction. Pennsylvania reported no aminorex "positives" after 2006, and eventually negotiated settlements with their horsemen. In Canada, there were no aminorex "positives" tested after 2007. On the other hand, Ohio continued testing aminorex 'positives' until at least 2009, apparently largely in Standardbred racing. Since drug testing continues at about the same rate in each of these North American racing jurisdictions, these changed positive call rates are presumably due to horsemen recognising levamisole as the source of many or most of these aminorex positives, and possibly also to regulatory re-evaluation of the forensic significance of very low concentration aminorex identifications.

More recently, in October of 2009, we received a communication from a colleague of an English horse trainer who recently had two pemoline 'positives' and one apparently related tetramisole 'positive' called (Tobin 2009). Responding to this request, we revisited the then well-established link between levamisole and aminorex, and reviewed the chemistry of levamisole, aminorex and pemoline. The structure of pemoline is closely related to that of aminorex, being a simple oxidation product of aminorex. It is therefore easy to extend the levamisole/ aminorex connection from levamisole, (the levo isomer of tetramisole, ergo the name levamisole) to aminorex and then, by simple oxidation, to pemoline. Im summary, any horse administered either levamisole or possibly tetramisole is at risk of producing either aminorex or pemoline positives, or, conceivably both, as set forth in this abbreviated chemical reaction scheme in Figure 1.

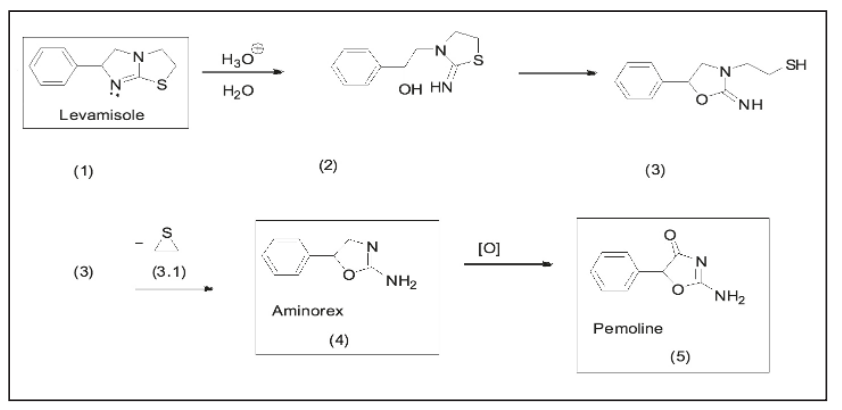

Figure 1: Proposed conversion of Levamisole to Aminorex to Pemoline. Levamisole (1) can protonate to form intermediate 2, which can undergo alkylation of the double bond to form 3 , with loss of thiirane, 3.1 , to yield Aminorex 4. Aminorex can then undergo biological oxidation [0] to form Pemoline 5 (Eisenberg 2008; Ho, 2009).

Furthermore, pemoline has an unusually long (150 hour) apparent terminal half-life in horse urine and is thus likely to yield prolonged 'detection times' in post-race urine testing in horses, as shown by members of our research group 30 years ago (Tobin 1981). As such, it seems probable that one of the last metabolites to be detected after levamisole administration would be pemoline, as has apparently happened in the case of our English colleague, 
and as has also apparently occurred previously in English racing (Tobin 2009).

Consistent with this proposed mechanism, the horses involved in the recent English pemoline 'positive' had been administered levamisole on the recommendation of the trainer's veterinarian. Levamisole was administered as a clear yellow solution containing 3\% w/v Levamisole Hydrochloride Ph.Eur. Levacide 3\% Drench, which is described as a broad spectrum anthelmintic for use in the treatment and control of nematode infections in cattle and sheep. at $2.5 \mathrm{ml}$ per $10 \mathrm{~kg}$ of bodyweight (.http://www. norbrook.co.uk/products/ProductPrintable.cfm/product_ Key/425/CatKey/1/Section/Veterinary_Products/). Consistent with the above chemistry, two of these horses yielded positives for pemoline and a third horse was reported positive for Tetramisole, entirely consistent with the close structural relationship between levamisole and tetramisole. (Tobin 2009).

With respect to the matter of the regulatory outcome of this very unusual circumstance, we immediately communicated the results of our researches as outlined in this report to the trainer and veterinary surgeon involved. Additionally, we can report that these findings were of relevance to an enquiry held by the British Horseracing Authority Disciplinary Department, in that "the Panel was satisfied that the source of both pemoline and tetramisole was a five-day course of $120 \mathrm{ml}$ of Levacide for [horse \#1] and [horse \#2] and [horse \#3] and a four-day course for [horse \#4], which commenced on August 18, 2009 and was given under veterinary advice." (http://www.britishhorseracing. com/resources/about/whatwedo/disciplinary/ disciplinaryDetail.asp?item $=091148$ )

In conclusion, administration of levamisole and presumably also tetramisole to horses which are likely to be medication tested should be avoided. This is because in the horse levamisole, and possibly also tetramisole can metabolise to two central nervous system stimulants, aminorex and pemoline, and as such have been associated with 'positive' calls for each of these substances in post-race urines. In point of fact, in the US, the link between levamisole administrations and aminorex identifications has led to the reclassification of levamisole, previously a substance of essentially no regulatory interest, as an $\mathrm{ARCl}$ class two agent (ARCl website). This is an explicit regulatory recognition of the ability of levamisole administration to produce aminorex 'positives' and now, based on these English reports, pemoline 'positives' in post-race urines. colostrum-fed neonatal dairy calves. Comp. Clin. Path. 13, 132-136.

Molina, V.A.; Orsingher, O.A.; (1981) Effects of Mg-pemoline on the central catecholaminergic system. Arch. Int. Pharmacodyn. 251, 66-79.

Mushalko, J., 2010, email correspondence, Pennsylvania Racing Commission.

Pellegrini, F., (2010), Aminorex racehorse mystery clarified, http://www.succeeddcp.com/sdcp_upload/Aminorex Release FINAL. http://www.britishhorseracing. com/resources/about/whatwedo/disciplinary/ disciplinaryDetail.asp?item $=091148$

Soma, L.R.; Rudy, J.A.; Uboh, C.E.; Xu, F.; Snapp, H.M.; (2008) Pharmaco- Kinetics and effects of aminorex in horses. American Journal of Veterinary Research 69, 675-681.

Tobin, T., (1981) Drugs and the Performance Horse, 223225.

Tobin, T., 2010, personal communication, F. Pellegrini. Tobin, T., 2009, personal communication, D. A. Wilson. Uboh, C. E., 2010, personal communication.

Weber, M., personal communication, 2010.

Wong, A.S.Y.; Wong, C.H.F.; Soma, L.R.; Rudy, J.A.; Uboh, C.; Sams, R;. (2009) Aminorex and rexamino as metabolites of levamisole in the horse. Analytica Chimica Acta 638, 58-68.

\section{ACKNOWLEDGEMENTS}

Published as paper \#382 from the Equine Pharmacology Therapeutics and Toxicology Program at the Maxwell H. Gluck Equine Research Center and Department of Veterinary Science, University of Kentucky. Published as Kentucky Agricultural Experiment Station Article \# 10-14023 with the approval of the Dean and Director, College of Agriculture and the Kentucky Agricultural Experimental Station. This work was made possible by research support from The National Horsemen's Benevolent and Protective Association and the Alabama; Arizona; Arkansas; Canada; Charles Town, WV; Florida; lowa; Kentucky; Louisiana; Michigan; Minnesota, Nebraska, Ohio, Oklahoma, Ontario Canada, Oregon, Pennsylvania, Tampa Bay Downs, Florida; Texas; Washington State; and West Virginia Horsemen's Benevolent and Protective Associations.

\section{REFERENCES}

Gurtner, H.P.; (1985) Aminorex and pulmonary hypertension. A review; Cor Vasa 27, 160-171. Ho, E.N.M.; Leung, D.K.K.; Leung, G.N.W.; Wan, T.S.M.; Mohri M.; Seifi H.A.; Zamani Sani, S.H.; (2005).Effects of oral administration of levamisole on non-specific immunity, serum proteins and health in normal 